\title{
MEASURING ONLINE LEARNING READINESS DURING CORONA VIRUS PANDEMIC: AN EVALUATIVE SURVEY ON HISTORY TEACHERS AND STUDENTS
}

\author{
Atqo Akmal ${ }^{1}$, Asyrul Fikri ${ }^{2}$, Tien Rahmawati ${ }^{3}$, Zulfa Hendri ${ }^{4}$, Noviyana Sari ${ }^{5}$ \\ ${ }^{1}$ History Education Departemen, Universitas Islam Negeri Imam Bonjol \\ ${ }^{2}$ History Education Departemen, Universitas Riau, Indonesia \\ ${ }^{3}$ Musyawarah Guru Mata Pelajaran Sejarah Kabupaten Indragiri Hilir \\ ${ }^{4}$ History Education Departement, Universitas Negeri Jakarta \\ ${ }^{5}$ Economic Education Departement, Universitas Sebelas Maret \\ latqoakmal@gmail.com, ${ }^{2}$ asyrul.fikri@lecturer.unri.ac.id, ${ }^{3}$ tienrahmawatimpd@gmail.com, ${ }^{4}$ zulfahendri@gmail.com, \\ ${ }^{5}$ noviyana.arifin@gmail.com
}

\begin{abstract}
Corona virus pandemic has rapidly changed the way of life as well as the way of learning system in entire world. The need for information and communication technology (ICT) competencies and improved digital infrastructure are the main requirement to conduct the distance learning or online learning. In addition, both teachers and students must be adapted with this "abnormal" condition since the online learning has been officially applied by Indonesian government during March until end of 2020. However, a quick change to online learning has left students and teachers with insufficient time to prepare. This study focused on the readiness of teachers and students to conduct online learning. The readiness aspects considered in this study were the digital competence of users and digital infrastructure readiness to support the technical issue of online learning. The design of this study was evaluative survey and the data were collected equally by using online survey platform from three hundreds high school students and thirty history teachers. To maintain the equalization of the data, the respondent was divided into two clusters, based on the rural region and urban region. This study found that both students and teachers were mainly not well prepared and fully ready to conduct online learning due to technical problems such as stability of internet access, the internet network availability, and financial issues. Meanwhile, the digital competence aspect was not the major problem for both teachers and students because the majority of respondents (above 80\%) declared that they had no trouble in using the device or running the online learning platform. Consequently, in along-term effect, the unbalanced preparation of online learning could be resulted in digital divided which rose the inequality of the education quality among the learners.
\end{abstract}

Keywords: online learning readiness, history education, pandemic

\section{MENGUKUR KESIAPAN BELAJAR ONLINE SAAT PANDEMI VIRUS CORONA: SURVEI EVALUASI GURU DAN SISWA SEJARAH}

\begin{abstract}
ABSTRAK
Pandemi virus Corona telah dengan cepat mengubah cara hidup, begitu pula sistem pembelajaran di seluruh dunia. Kebutuhan akan kompetensi teknologi informasi dan komunikasi (TIK) dan infrastruktur digital yang ditingkatkan menjadi syarat utama untuk menyelenggarakan pembelajaran jarak jauh atau online. Selain itu, baik guru maupun siswa harus disesuaikan dengan kondisi "tidak normal" ini. Sejak pembelajaran online atau pembelajaran jarak jauh telah resmi diterapkan oleh pemerintah Indonesia selama bulan Maret hingga akhir tahun 2020. Namun, perubahan yang cepat pada pembelajaran online membuat siswa dan guru memiliki sedikit waktu untuk bersiap. Penelitian difokuskan pada kesiapan guru dan siswa untuk melakukan kesiapan pembelajaran online. Aspek kesiapan yang dipertimbangkan dalam penelitian ini adalah kompetensi digital pengguna dan kesiapan infrastruktur digital untuk mendukung masalah teknis pembelajaran online. Desain penelitian adalah survei evaluatif dan data dikumpulkan secara merata menggunakan platform survei online dari tiga ratus siswa SMA dan tiga puluh guru sejarah. Untuk menjaga pemerataan data, responden dibagi menjadi dua cluster, berdasarkan wilayah perdesaan dan perkotaan. Menurut hasil penelitian, sebagian besar siswa dan guru kurang siap dan belum sepenuhnya siap untuk melaksanakan pembelajaran online karena adanya kendala teknis seperti stabilitas akses internet, ketersediaan jaringan internet, dan masalah keuangan. Sedangkan aspek kompetensi digital belum menjadi masalah utama baik bagi guru maupun siswa, karena mayoritas responden (di atas $80 \%$ ) menyatakan tidak mengalami kesulitan dalam menggunakan perangkat atau menjalankan platform pembelajaran online. Akibatnya, dalam efek jangka panjang, ketidakseimbangan dalam persiapan pembelajaran online dapat mengakibatkan terbagi digital yang meningkatkan ketimpangan kualitas pendidikan di antara peserta didik.
\end{abstract}

Kata Kunci: kesiapan belajar online, pendidikan sejarah, pandemi

\begin{tabular}{|c|c|c|}
\hline Submitted & Accepted & Published \\
\hline 02 Oktober 2020 & 03 Januari 2021 & 26 Januari 2021 \\
\hline
\end{tabular}

\begin{tabular}{|l|c|c|}
\hline Citation & $:$ & $\begin{array}{r}\text { Akmal, A., Fikri, A., Rahmawati, T., Hendri, Z., \& Sari, N. (2020). Measuring Online Learning Readiness during Corona } \\
\text { Virus Pandemic: An Evaluative Survey on History Teachers and Students. Jurnal PAJAR (Pendidikan dan } \\
\text { Pengajaran), 5(1), 98-110. DOI : http://dx.doi.org/10.33578/pjr.v5i1.8169. }\end{array}$ \\
\hline
\end{tabular}




\section{INTRODUCTION}

In the beginning of 2020, Corona Virus (Covid-19) has wreaked havoc around the world, since then it has spread universally and resulted in pandemic that brought major impact on human society. Latest report, there were thousands Indonesian had been infected by Covid-19, and the number of victim has been improved every day. As suggested by the Epidemiologist, to prevent transmission of Covid-19 the Indonesian government has issued prohibition of social gathering and suggested people to reduce activity outside home. Moreover, the government has set alert on the threat of Covid-19 by launching lockdown on several regions in Indonesia which had badly impacted by the spread of Corona- 19 . As the rise of people infected and still there is no sign of vaccine solution, it could be means that we must adapt to a "new normal" period by adjusted our way to live alongside Covid-19 threat.

United Nations Education Scientific and Cultural Organization UNESCO General Director, Audrey Azoulay, said that "we are entering uncharted territory and working with countries to find hi-tech, low-tech and no-tech solutions to assure the continuity of learning" (Huang, Liu, Tlili, Yang, \& Wang, 2020) which means that regarding the condition the learning activities should be done even in the midst of Covid-19 outbreak and using all technologies capabilities that we had. At March 2020, UNESCO reported that Covid-19 outbreak has impacted nearly 300 million students across the world and threatened their future education rights. Thus, to compromise with a new normal period, the distance and online learning are solutions to carry out learning activity without social gathering and minimize physical contact. Whether we are ready or not, the transition brings a new order and a new development, as the information age which raised the network society has begun long ago even before the pandemic (Castells, 2009). Quick changes from face-to-face learning to online learning have surprised the educational practitioners and institutions, without any preparation teachers and students are forced to conduct teaching and learning activity by online course.

One of the main factors shaping the effectiveness of online learning is readiness (Artino, 2009; Galy, Downey, \& Johnson, 2011; Kruger-Ross \& Waters, 2013). Basically, readiness can be defined as a prepared condition, either psychologically or technically (Borotis \& Poulymenakou, 2004; Valtonen, Kukkonen, Dillon, \& Väisänen, 2009). It reflects individual condition and enabled-characteristics to use ICTs tools. Online learning readiness plays a significant role to encourage learners to be involved in online learning activities; and it can be perceived as a crucial factor to be taken into account in any development of online learning environment (Ilgaz \& Gülbahar, 2015). Moreover, Yukselturk \& Bulut (2007) found that online learning readiness was one of the strongest predictors of satisfaction for students in online courses.

Recent studies about online learning readiness defined in various form of explanations. Blayone, (2018) concluded that readiness emphasize different dimension which are the actors (e.g. users, students, and teacher), desirable attitudes (e.g. optimism and acceptance), learning contexts (e.g. formal and informal) and outcomes (e.g. learning satisfaction and significant benefit). Online learning readiness can be estimated by evaluating a user's competency in using technological tools (Schreurs, Ehlers, \& Sammour, 2008). In terms of autonomous learning, Tang \& Lim (2013) defined the online learning readiness could be describe in three major features: choices for online learning as opposed to face-to-face learning; competence and confidence in using the information and communication technology (ICT) tools; and ability to learn separately. Even tough, there a similarity of explanation among the studies which views the user competence to operate technological tools as basic need to perform the online learning.

On the other hand, online learning could achieve success when socio-cultural environment, supporting digital infrastructure, host institutions, 
and human participation are well prepared (Blayone, 2018). Most of studies about online learning readiness are rarely mentioned the role of technical factors to perform online learning, because majority of online learning studies were conducted in developed country which have better infrastructure, plenty source of funding, and development equality across the region. It means that technical factors are rarely being main obstacle. Obviously, the integration of technology in educational systems is a key driver to enhance teaching and learning, and the educational policy-makers should invested heavily in building and maintaining ICT infrastructure in the schools (Pelgrum, 2001).

In the developing country, socioeconomic aspect, inter-connectivity access, and inequality rate of development are the main obstacles to integrate the ICT into education (Chipembele \& Bwalya, 2016). Digital infrastructure being technical aspect which cannot be marginalize in measuring online learning effectiveness. On the other side, development of Indonesia digital infrastructure is still unbalanced between the digital infrastructure growth of urban and the rural, mostly the usage of internet and its digital features are dominated by the urban, thus it reflected a gap between the development of digital in Indonesia (Nasution, 2016). Consequently, the digital infrastructure readiness could not be ignored to measure readiness of online learning.

In the early of Covid-19 outbreak in Indonesia, several studies about distance and online learning has been conducted by several researchers, for example Wargadinata, et al (2020) simply described learning media which used by teacher during early distance learning; Allo (2020) investigated learners' perception of English for Foreign Language course which he found that perceived online learning was very helpful but also concerned the availability of internet access and financial issue; Purwanto et al., (2020) recorded the advantages and disadvantages of working at home during Covid19 pandemic; Wajdi et al., (2020), Zaharah \& Kirilova (2020) was discussed the government educational policies during Covid-19 pandemic;
Nirwana (2020) illustrated the students' difficulties when attending online course. Hence, this study tried to evaluate the teacher and student responded after over six months implementation of distance and online learning due the Covid-19 pandemic, especially focused on the readiness of users (digital competence) and the readiness of digital infrastructure (technical support).

\section{LITERATURE REVIEW}

Hypothetically, students' self-readiness takes an important role to support learning activity (Blignaut \& Els, 2010), either in the face-to-face learning or online learning. As part of online learning readiness, digital competence is one of main aspect which needed to perform online learning, it closely related to digital skill, digital literacy, and e-competence. Ala-Mutka (2011) briefly composed digital competencies term as sets of knowledge, skills and attitudes relating to the purposeful and effective use of digital technologies. In term of online learning, information and communication technology (ICT) are basic requirement of user to perform online course.

Teacher, as the designer of instruction, should be integrated the usage of ICTs technologies into learning environment. Pontifica Universidad Javeriana and UNESCO (2016) composed teacher's ICT integration levels in education consisting three levels ability: designfamiliarization, implement-utilization, and assestransformation. First, design skill indicated that teacher enabled to establish ICT-enabled settings for meaningful learning and comprehensive education or this skill relates how teacher familiarizes with ICT. Second, implement skill describe teacher's ability to using or harnessing ICT for meaningful learning experiences. Third, assess skill which means teacher's ability to measure the effectiveness of ICT education settings to promote meaningful student learning.

At the initial level of adoption (integration), teachers use ICTs as a tool for optimizing the presentation of content, communicating and conveying information. In advanced levels of adoption, the internal dynamics of education practices are improved 
through the inclusion of ICTs. At those levels, ICTs become tools that facilitate knowledge construction (reorientation) or even become powerful mediators generating dynamics that would be impossible without ICTs (evolution). The classification is dynamic and can include variable and differentiated teacher profiles based on particular approaches to technology, subject, education setting and their individual stage on the journey to adoption.

In addition, student as participant should also have readiness to perform online learning. Obviously, student readiness is one of key factor for effective online learning. Through good learning readiness, students can attend the learning actively and easily understand the lesson delivered during the learning process (Antoun, Nasr, \& Zgheib, 2015). Andrei (2019) concluded that student readiness includes skill and mental readiness (patience \& persistence), tool readiness (ware \& internet), and financial readiness (cost \& time). Student readiness to conduct online learning or distance learning can be measured by three indications, (1) student preferences for form of delivery, (b) student confidence in electronic communication learning, and (3) learner's ability to engage autonomous learning (Warner, Christie, \& Choy, 1998)

For measuring readiness to conduct online learning, e-readiness, or other similar term should be included the role of digital infrastructure as a fundamental requirement in building education connectivity, because the quality of internet connection is one of component in digital infrastructure. In 1998, Computer Systems Policy Project the first project attempted to study about network connectivity variable on the online learning readiness (Chipembele \& Bwalya, 2016; Nabavi \& Davidrajuh, 2009). Most of scholars tend to focus on the digital competencies as the main factor influenced online learning readiness, because mainly early research about e-learning readiness was conducting in the developed country which has more satisfied connectivity infrastructure. The gap between developed and developing country has generated various levels e-readiness levels among the countries. For example, the lack good infrastructures (Ifinedo \& Davidrajuh, 2005), low-expenditure in internet bandwidth and ICT infrastructure (Chipembele \& Bwalya, 2016); both circumstances have resulted in low opportunities to harnessing the ICT in the developing countries. As explained above, in this study the role of digital infrastructure would be a major consideration to measure the online learning readiness.

\section{RESEARCH METHODS}

The study was conducted at June-July 2020 in the Indragiri Hilir Regency, Province of Riau, Indonesia. The design of this study was evaluative survey research. Evaluative survey was selected because it is an effective method to engage a sizeable population (Hollins Martin, Forrest, Wylie, \& Martin, 2014) and it is suitable approach to measure public perception. The data was collected from 300 students $\left(n_{1}=300\right)$ and 30 history teachers $\left(n_{2}=30\right)$. To maintain equally distribution of data, urban and rural cluster are considered in this study, for detail information see Table 1. The study was collaborated with the History Teacher Council of Indragiri Hilir Regency (Musyawarah Guru Mata Pelajaran Sejarah Indragiri Hilir). The member of the council is around fifty history teacher member coming from the entire region. Thus, it made the study possible nearly matching the population size. Even the study did not reach all of council members due to lack of communication infrastructure in the some rural region, the ratio of data was considerably high. 
Table 1. Characteristic of Respondent STUDENT

\begin{tabular}{llc}
\hline \multicolumn{2}{c}{ STUDENT } \\
\hline Cluster & Distribution of Respondent (by School) & Number of Respondent (Student) \\
\multirow{3}{*}{ Rural } & SMA Negeri 2 Enok & 150 \\
& SMA Sapat & \\
\hline
\end{tabular}

Urban

SMA Negeri 1 Tembilahan

MAN 1 Indragiri Hilir

\section{TEACHER}

Cluster Distribution of Respondent (by School)

Number of Respondent

Indragiri Hilir

Regency

Various schools across the region

30

The questionnaire was developed based on literature review as the main objective of the study aiming to investigate the online learning readiness of the teacher and student. Two components of online learning readiness in the study consists the digital competences (both teacher and students) and digital infrastructure (internet connectivity, network stability, and other technical factors). In addition, the authors also tried to collect information about the effect of quick change -from traditional face-to-face learning to online learning- toward the respondent. Thus, the questionnaire contained two sections of question (see Table 2): first section was intended to measure the respondents' digital competences; second section was purposed to see the respondents' perception toward digital infrastructure readiness; The questionnaire was disseminated to the respondent using online google form survey. Finally, the data was presented in statistical descriptive before analyzed properly to draw any conclusions.

Table 2. List of Questions

\begin{tabular}{|c|c|c|}
\hline Readiness Factor & Student & Teacher \\
\hline \multirow{3}{*}{ Digital competences } & $\begin{array}{l}\text { 1a. Dapatkah anda menggunakan aplikasi } \\
\text { atau media belajar daring? } \\
\text { (Can you using online learning media or } \\
\text { application?) }\end{array}$ & $\begin{array}{l}\text { 1a. Dapatkah anda menggunakan aplikasi } \\
\text { atau media belajar daring? } \\
\text { (Can you using online learning media or } \\
\text { application?) }\end{array}$ \\
\hline & $\begin{array}{l}\text { 1c. Apakah anda memanfaatkan aplikasi } \\
\text { pengetahuan berbasis teknologi informasi } \\
\text { sebagai sarana belajar? } \\
\text { (Did you harness ICT as learning media?) }\end{array}$ & $\begin{array}{l}\text { 1c. Apakah anda memanfaatkan aplikasi } \\
\text { pengetahuan berbasis teknologi informasi } \\
\text { sebagai sarana belajar? } \\
\text { (Did you harness ICT as teaching media?) }\end{array}$ \\
\hline & $\begin{array}{l}\text { 3a. Dari beberapa aplikasi belajar di } \\
\text { bawah ini, pilihlah yang anda dapat } \\
\text { mengoperasikannya. } \\
\text { (From the options below. Choose the } \\
\text { online learning media which you can use!) }\end{array}$ & $\begin{array}{l}\text { 3a. Dari beberapa aplikasi belajar di } \\
\text { bawah ini, pilihlah yang anda dapat } \\
\text { mengoperasikannya. } \\
\text { (From the options below. Choose the } \\
\text { online learning media which you can use!) }\end{array}$ \\
\hline Digital & 2a. Apakah anda terkendala dengan & 2a. Apakah anda terkendala dengan \\
\hline
\end{tabular}




\begin{tabular}{|c|c|c|}
\hline Infrastructures & $\begin{array}{l}\text { ketersediaan akses internet untuk belajar } \\
\text { daring? } \\
\text { (Did you troubled by availability of } \\
\text { internet access to attending the online } \\
\text { course?) }\end{array}$ & $\begin{array}{l}\text { ketersediaan akses internet untuk belajar } \\
\text { daring? } \\
\text { (Did you troubled by availability of } \\
\text { internet access to conducting the online } \\
\text { learning?) }\end{array}$ \\
\hline & $\begin{array}{l}\text { 2b. Apakah anda terkendala dengan } \\
\text { kestabilan akses internet saat } \\
\text { melaksanakan belajar jarakjauh? } \\
\text { (Did you concern about the network } \\
\text { stability when attending the online } \\
\text { course?) }\end{array}$ & $\begin{array}{l}\text { 2b. Apakah anda terkendala dengan } \\
\text { kestabilan akses internet saat } \\
\text { melaksanakan belajar jarakjauh? } \\
\text { (Did you concern about the network } \\
\text { stability when conducting the online } \\
\text { learning?) }\end{array}$ \\
\hline & $\begin{array}{l}\text { 2c. Apakah biaya paket data menjadi } \\
\text { masalah untuk menerapkan belajar } \\
\text { daring? } \\
\text { (Did you concern about network data cost } \\
\text { to attending the online course?) }\end{array}$ & $\begin{array}{l}\text { 2c. Apakah biaya paket data menjadi } \\
\text { masalah untuk menerapkan belajar } \\
\text { daring? } \\
\text { (Did you concern about network data cost } \\
\text { to conducting the online learning?) }\end{array}$ \\
\hline
\end{tabular}

\section{RESULTS AND DISCUSSION}

The result of study would be described based on the survey in descriptive statistic. The discussion would be narrated on three sections: first section describes about digital competencies of user (teacher and student); and second section explained about the respondents' perceptions on digital infrastructure readiness.

\section{Digital Competencies}

The summary of respondent response in their ability to use the ICT feature to perform online learning is showed on the Figure $\mathbf{1}$ and Figure 2. Mostly, both teacher and student were admitted that they have no trouble in using online learning platform. As the result of survey showed that majority of the respondent $(88,3 \%$ and 83.3 $\%$ ) were admitted that they are able to use online learning media. Furthermore, as described on the Figure 2, majority of respondent declared that they were able to harnessing the ICT features as learning media.

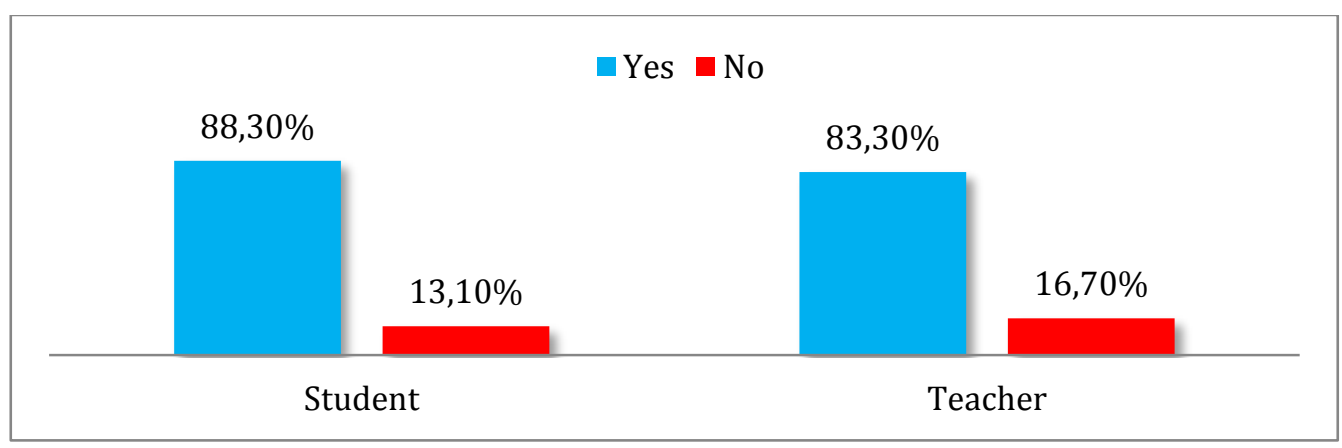

Figure 1. Digital Competencies: Can you using online learning media or application? 


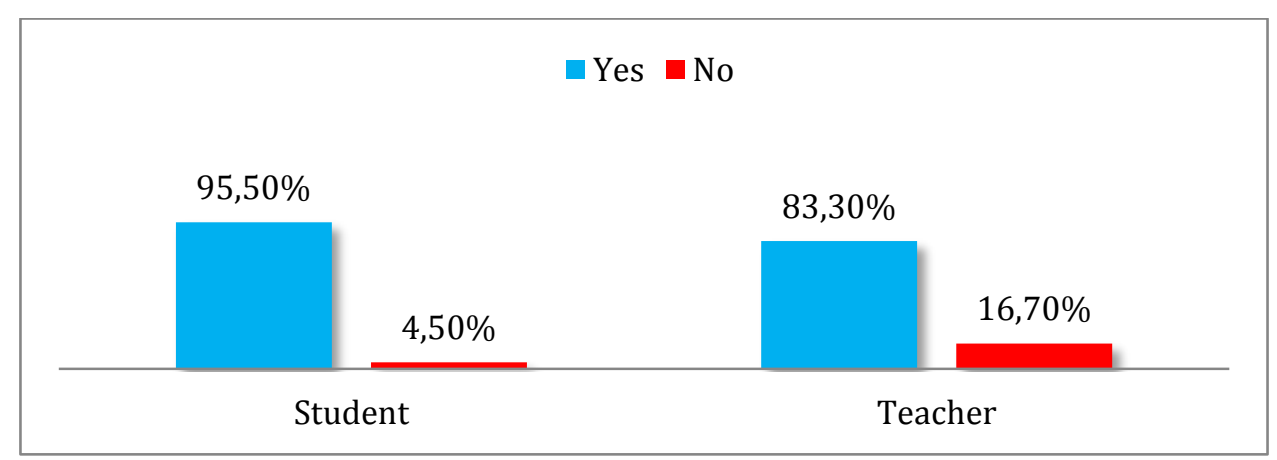

Figure 2. Digital Competencies: Did you harness ICT as learning media?

As shown in the Figure 2, students' acceptance percentage is higher than in Figure 1. (Muharina \& Kelana (2018) was examined Indonesian students' e-learning readiness; the study concluded that most of the students were already able to use the ICT features. Yet it simply relates as the millennial generation usually having no trouble in adapting such of online learning environment. They have well-connected and fluency in using the ICT to connected with friends and classmates, searching information, or selflearning via online tutorial assistance (Beddoe, $e t$ $a l, 2018)$. In line with it, Gay (2016) found that electronic learning system could shaped the user ability to routinely communicating with persons using electronic technologies; predisposition towards embracing and using new technologies; and being self-motivated and independent learners. Indeed, before performing online learning activities the users are required to have basic technology competence such as using email, internet, and manage the document (Greaves, Bradley, \& Holley, 2013), thus these skills were probably has been mastered by the user, which they were able to use more complicated online learning application.
On the other hand, Sari, (2012) concerned about the inability of Indonesian teacher which trained on conventional way to adapt on the recent digital environment. Surprisingly, it is opposed with the teacher respondent result which majority of respondent declared that they have already confidence in using online learning tools. For this trend of change caused by Covid-19 pandemic, Niranjan (2020) viewed the pandemic as a "blessing in disguise" on the global education, which he means that a forced change to online learning approach has influenced the educators ability in using the ICT features. In addition he argued that the pandemic has taught the educators to be more prepared for best education in the postpandemic era with better and well-equipped education. In line with it, Mailizar, Almanthari, Maulina, \& Bruce (2020) concluded that teachers' backgrounds had no impact on the level of barriers in conducting online learning. While, Gay (2016) mentioned that the main benefit of using electronic learning system is enhanced teaching skills of instructor, beside the main challenge is lack of social interaction. 


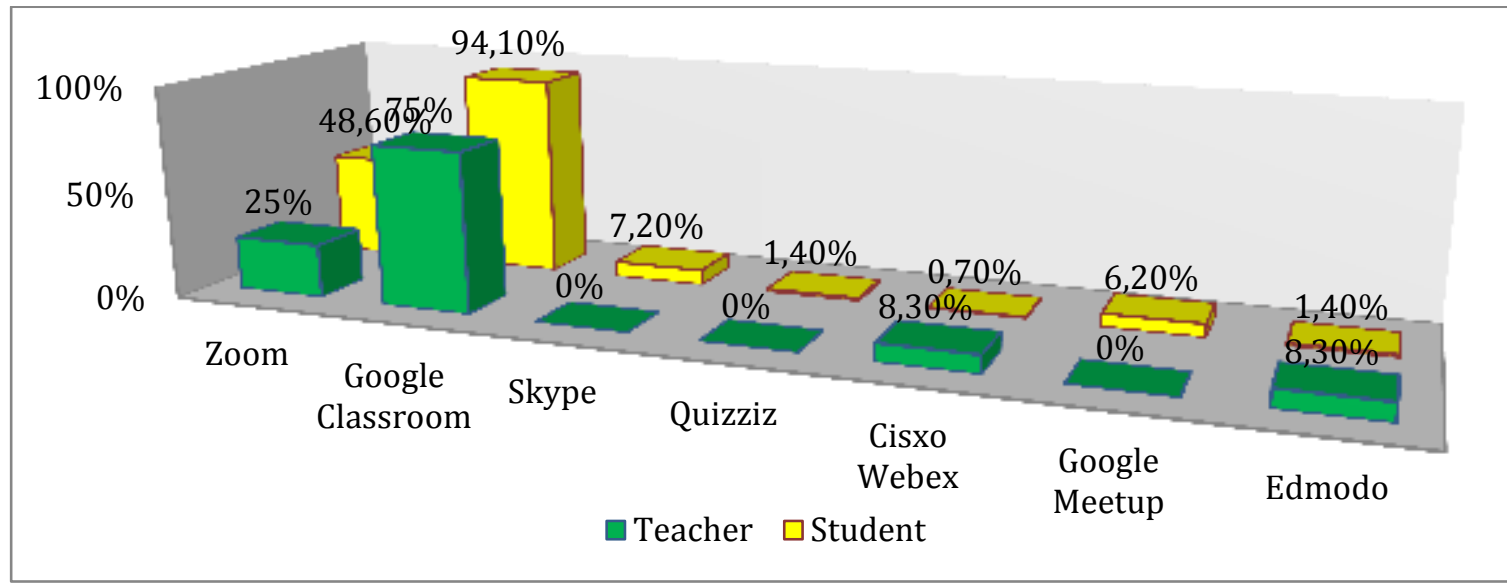

Figure 3. Digital Competencies: From the options below. Choose the online learning media which you can use!

The result summary of the online learning platform which commonly used by both student and teacher is described in the Figure 3. The overall responses showed that the usage of Zoom Cloud Meetings and Google Classroom are respectively dominated the other compatriots in providing services for online learning requirement, but minor responses also shown the respondents have already known about the other features which can be harnessed for online learning.

\section{Teacher and Students Perception on Digital Infrastructure Readiness}

Question on Student: Did you troubled by availability of internet access to attending the online course? Question on Teacher: Did you troubled by availability of internet access to conducting the online learning?

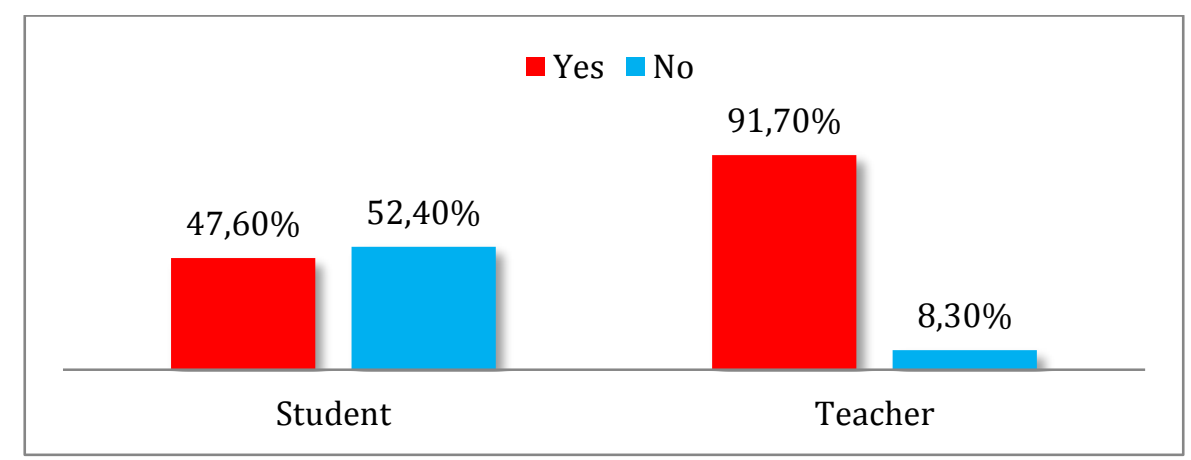

Figure 4. Digital Infrastructure

Figure 4 showed the perception of respondent in similar way question, about network availability. Overall, there is a different statistical perception between student and teacher toward the network availability. $52.4 \%$ student declared that they have no problem with the internet access while the other complained about availability of internet access, the more comprehensive analysis about the network availability could be compared with question $2 \mathrm{c}$ 
(Figure 6) which we could consider whether the problem due to technical error or financial problem in providing internet cost. Tough, the percentage of respondent who found the internet access trouble during online learning is statistically rated high, with overall teacher respondent valued $91.7 \%$ and the student valued $47.6 \%$.

Question on Student: Did you concern about the network stability when attending the online course?
Question on Teacher: Did you concern about the network stability when conducting the online course?

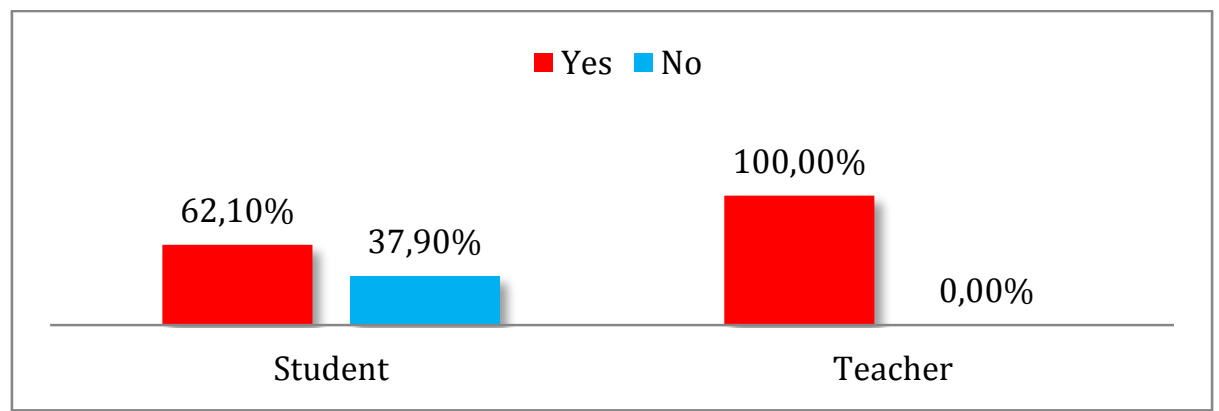

Figure 5. Digital Infrastructure:

In figure 5 showed the overall responses of the respondent concerned about the network stability during the online learning course. They have complained that stability of internet connection was disturbed the online learning, surely it would giving an impact to the learning experience at whole. In line with it, Allo (2020) also reported similar findings which the availability of internet access and financial issue were influenced the implementation of online learning. Then, Nirwana (2020) also found that the participants of online course were facing some technical problems, lacking of sense of community, constraining time, and the difficulties in understanding the objectives of the online courses.

Internet access in Indonesia is still relatively slow, poor network coverage, and expensive (Budiman \& Wicaksono, 2017). As the highly demand of quality internet access in order to support the online learning, the improvement of digital infrastructure is urgently needed as the end of pandemic still no sign to be over. The large population, geographical difficulties, and lack of servers (Marius \& Pinontoan, 2013) are viewed as main obstacles in building quality internet access and inter-connectivity across the archipelago. Thus, it reflects some digital divide in digital infrastructure in Indonesia. And conclusively, it means that Indonesian infrastructure is not yet ready to provide quality online learning experience.

Actually, the distributed of digital infrastructure and wireless development seems to fit the needs and requirement of a country like Indonesia with its geographical and economic challenges (Galinium, Defindal, \& Melissa, 2012) which the rural or isolated region could be reached by the wireless interconnectivity provided by internet network. As stated by Norris (2000) that there is an expectation on internet to be powerful force which able to transforming existing patterns of social inequality. Unquestionably, as the pandemic raising demand on the distance learning, rural or isolated region should be giving any accelerated digital infrastructure development.

DiMaggio, Hargittai, Neuman, \& Robinson, (2001) defined the digital divide as inequality of access to the internet. The importance for reducing the gap in digital divided is to diminish the inequality of social-economic problems caused by digital divided. For example, Blank \& Groselj (2015) simply described the first level of digital divided would separate who is online or offline; or who is have/have not the 
connectivity device (e.g. computer, internet access, etc), moreover, it could implicate on the differences in ICT skills, financial circumstances, and social capital. Question on Student: Did you concern about network data cost to attending the online course?
Question on Teacher: Did you concern about network data cost to conducting the online course?

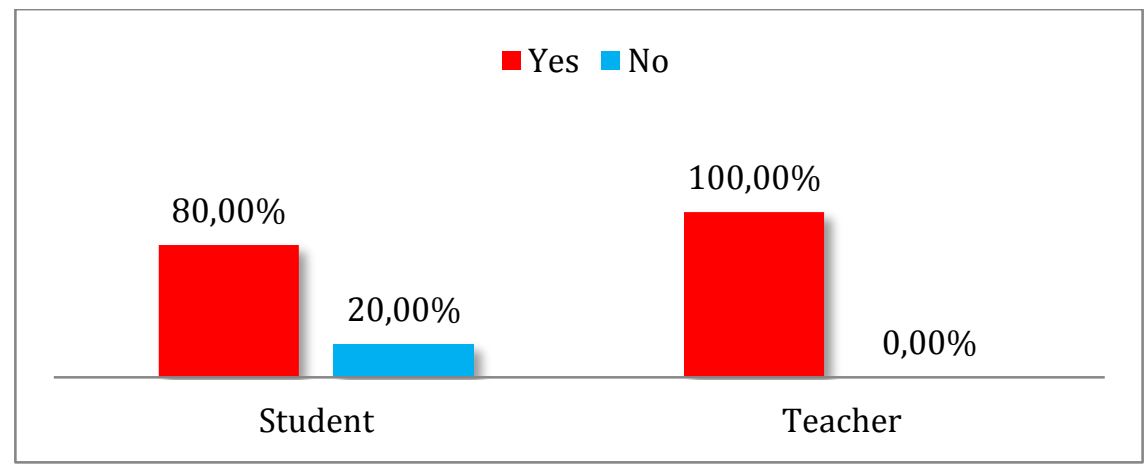

Figure 6. Digital Infrastructure

Figure 6 showed the financial issue of respondent to perform online learning. Majority of respondent, both teacher and student, were complained about the economic consequences during distance learning. As mentioned in the introduction of this study, social-economic factor also have major impact on the online learning readiness. Many students in the developing countries are struggled to get a quality education due to cost of internet access and the device ownership. They are under threat of "digital exclusion", a condition where a population suffering lags in its adoption of ICT through circumstances (Warren, 2007). Pick \& Nishida (2015) suggested telecommunication development policies to use spatial analysis for prioritizing the rural, though without a constructive approach the already faster urban will get faster, leaving the rural area behind and increasingly the gap between the urban and rural. Further impact on the gap of digital infrastructure could be affected the implementation of distance and online learning.

\section{CONCLUSIONS AND \\ RECOMMENDATION}

Overall, the Covid-19 pandemic has brought major impact on education which resulted in forced situation to changes from traditional face-to-face learning into distance and online learning. In this case, student and teacher should adapt to a new learning environment, and prepared themselves to integrate the ICT into teaching and learning activities. Based on the study, majority of teacher and student are technically and mentally ready to perform the online learning. However, the readiness of digital competencies is not simultaneously coupled with the readiness of digital infrastructure. The lack of network availability coverage in entire region, quality and stability of internet access, and internet bandwidth cost are the main obstacles to perform online learning. As the respondent frequently found difficulties dealing with these problems, the distance and online learning should be continue due to worsened pandemic. Consequently, in long-term effect, the unbalanced in preparation of online learning could be resulted in digital divided which raise the inequality of quality education between the learners.

First, the urgently requirement in implement distance and online learning is the improvement of digital infrastructure and freely access bandwidth for education purposed. The Indonesian government's educational policies should prioritize in dealing with basic requirement of digital infrastructure and integrating ICT on education, either during pandemic or postpandemic period. 
Second, for further research, it is important to considering extension to other variable that influenced online learning readiness, such as teacher age and experiences (digital competence), device ownership (digital infrastructure). The authors suggested focusing on examining the differences effect of online learning between teacher and student in the rural and urban region, the examination could be done by using established instrument of ereadiness/online learning readiness, or other similar term.

\section{REFERENCES}

Ala-Mutka, K. (2011). Mapping digital competence: towards a conceptual understanding. Institute for Prospective Technological Studies.

Andrei, E. (2019). Adolescent English Learners' Use of Digital Technology in the Classroom. Educational Forum. https://doi.org/10.1080/00131725.2018.14 78474

Antoun, J., Nasr, R., \& Zgheib, N. K. (2015). Use of technology in the readiness assurance process of team based learning: Paper, automated response system, or computer based testing. Computers in Human Behavior. https://doi.org/10.1016/j.chb.2015.01.003

Artino, A. R. (2009). Online learning: Are subjective perceptions of instructional context related to academic success? Internet and Higher Education. https://doi.org/10.1016/j.iheduc.2009.07.0 03

Beddoe, L., Hay, K., Maidment, J., Ballantyne, N., \& Walker, S. (2018). Readiness to practice social work in Aotearoa New Zealand: perceptions of students and educators. Social Work Education. https://doi.org/10.1080/02615479.2018.14 97152

Blank, G., \& Groselj, D. (2015). Examining internet use through a weberian lens. International Journal of Communication.
Blayone, T. (2018). Reexamining digital-learning readiness in higher education: Positioning digital competencies as key factors and a profile application as a readiness tool. International Journal on E-Learning: Corporate, Government, Healthcare, and Higher Education.

Blignaut, A. S., \& Els, C. J. (2010). Comperacy assessment of postgraduate students' readiness for higher education. Internet and Higher Education. https://doi.org/10.1016/j.iheduc.2010.02.0 07

Borotis, S., \& Poulymenakou, A. (2004). ELearning Readiness Components: Key Issues to Consider Before Adopting eLearning Interventions. Proceedings of $E$ Learn 2004--World Conference on ELearning in Corporate, Government, Healthcare, and Higher Education.

Budiman, E., \& Wicaksono, O. (2017). Measuring quality of service for mobile internet services. In Proceeding - 2016 2nd International Conference on Science in Information Technology, ICSITech 2016: Information Science for Green Society and Environment. https://doi.org/10.1109/ICSITech.2016.78 52652

Castells, M. (2009). The Rise of the Network Society. The Rise of the Network Society. https://doi.org/10.1002/9781444319514

Chipembele, M., \& Bwalya, K. J. (2016). Assessing e-readiness of the Copperbelt University, Zambia: case study. International Journal of Information and Learning Technology. https://doi.org/10.1108/IJILT-12-20150036

DESIGNING AN ASSESSMENT TOOL FOR MEASURING E-READINESS OF IRANIAN ICT COMPANIES. (2009). Issues in Information Systems.

DiMaggio, P., Hargittai, E., Neuman, W. R., \& Robinson, J. P. (2001). Social Implications of the Internet. Annual Review of Sociology. 
https://doi.org/10.1146/annurev.soc.27.1.3 07

Galinium, M., Defindal, I. P., \& Melissa, I. (2012). E-learning system introduction: Equality in education for teachers in rural area of Indonesia. In JCSSE 2012 - 9th International Joint Conference on Computer Science and Software Engineering. https://doi.org/10.1109/JCSSE.2012.6261 952

Galy, E., Downey, C., \& Johnson, J. (2011). The effect of using e-learning tools in online and campus-based classrooms on student performance. Journal of Information Technology Education:Research. https://doi.org/10.28945/1503

Gay, G. H. E. (2016). An assessment of online instructor e-learning readiness before, during, and after course delivery. Journal of Computing in Higher Education. https://doi.org/10.1007/s12528-016-9115-

Greaves, L., Bradley, C., \& Holley, D. (2013). Learning journeys: exploring approaches to learner digital literacy acquisition. Enhancing Learning in the Social Sciences. https://doi.org/10.11120/elss.2013.040200 03

Hollins Martin, C. J., Forrest, E., Wylie, L., \& Martin, C. R. (2014). An evaluative survey to assess the effectiveness of using an interactive workbook to deliver bereavement education to undergraduate student midwives. Midwifery. https://doi.org/10.1016/j.midw.2013.05.00 4

Huang, R. H., Liu, D. J., Tlili, A., Yang, J. F., \& Wang, H. H. (2020). Handbook on facilitating flexible learning during educational disruption: The Chinese experience in maintaining undisrupted learning in COVID-19 Outbreak. Smart Learning Institute of Beijing Normal University UNESCO.

Ifinedo, P., \& Davidrajuh, R. (2005). Digital divide in Europe: assessing and comparing the e-readiness of a developed and an emerging economy in the Nordic region. Electronic Government. https://doi.org/10.1504/EG.2005.007090

Ilgaz, H., \& Gülbahar, Y. (2015). A Snapshot of Online Learners: e-Readiness, eSatisfaction and Expectations. International Review of Research in Open and Distributed Learning. International Review of Research in Open and Distributed Learning. https://doi.org/10.19173/irrodl.v16i2.2117

Kruger-Ross, M. J., \& Waters, R. D. (2013). Predicting online learning success: Applying the situational theory of publics to the virtual classroom. Computers and Education.

https://doi.org/10.1016/j.compedu.2012.0 9.015

Mailizar, Almanthari, A., Maulina, S., \& Bruce, S. (2020). Secondary school mathematics teachers' views on e-learning implementation barriers during the COVID-19 pandemic: The case of Indonesia. Eurasia Journal of Mathematics, Science and Technology Education. https://doi.org/10.29333/EJMSTE/8240

Muharina, A. S., \& Kelana, B. (2018). E-leaming readiness measurement on Indonesian student from individual perspective: A case study. In Proceedings - 2017 International Conference on Sustainable Information Engineering and Technology, SIET 2017. https://doi.org/10.1109/SIET.2017.83041 63

Nasution, R. D. (2016). Pengaruh Kesenjangan Digital Terhadap Pembangunan Pedesaan (Rural Development). Jurnal Penelitian Komunikasi Dan Opini Publik.

Niranjan, P. . (2020). Corona virus Pandemic impact on Global Education: A Blessing in disguise. Sustainable Humanosphere.

Nirwana \& Muhlis (2020). Students' Social Presence and Perceived Learning Toward Cross Cultural Understanding Course in Online Classroom (An Evaluating of 
Learning Process during Pandemic Coronavirus). Elite Journal Volume 7 Nomor 1, June 2020.

Norris, P. (2000). The Worldwide Digital Divide: Information Poverty, the Internet and Development. Annual Meeting of the Political Studies Association of the UK, London School of Economics and Political Science.

Pelgrum, W. J. (2001). Obstacles to the integration of ICT in education: Results from a worldwide educational assessment. Computers and Education. https://doi.org/10.1016/S03601315(01)00045-8

Pick, J. B., \& Nishida, T. (2015). Digital divides in the world and its regions: A spatial and multivariate analysis of technological utilization. Technological Forecasting and Social Change. https://doi.org/10.1016/j.techfore.2013.12. 026

Purwanto, A., Asbari, M., Fahlevi, M., Mufid, A., Agistiawati, E., Cahyono, Y., \& Suryani, P. (2020). Impact of Work From Home (WFH) on Indonesian Teachers Performance During the Covid-19 Pandemic: An Exploratory Study. International Journal of Advanced Science and Technology.

Sari, E. R. (2012). Online learning community: A case study of teacher professional development in Indonesia. Intercultural Education.

https://doi.org/10.1080/14675986.2012.66 4755

Schreurs, J., Ehlers, U. D., \& Sammour, G. (2008). E-learning Readiness Analysis (ERA): an e-health case study of $\mathrm{e}$ learning readiness. International Journal of Knowledge and Learning. https://doi.org/10.1504/IJKL.2008.022066

Tang, S. F., \& Lim, C. L. (2013). Undergraduate Students Readiness in e-Learning: A Study at the Business School in a Malaysian Private University. INTERNATIONAL JOURNAL OF MANAGEMENT \& INFORMATION
TECHNOLOGY. https://doi.org/10.24297/ijmit.v4i2.1900

Valtonen, T., Kukkonen, J., Dillon, P., \& Väisänen, P. (2009). Finnish high school students' readiness to adopt online learning: Questioning the assumptions. Computers and Education. https://doi.org/10.1016/j.compedu.2009.0 4.014

Wajdi, M. B. N., Iwan Kuswandi, Umar Al Faruq, Zulhijra, Z., Khairudin, K., \& Khoiriyah, K. (2020). Education Policy Overcome Coronavirus, A Study of Indonesians. EDUTEC: Journal of Education And Technology. https://doi.org/10.29062/edu.v3i2.42

Warner, D., Christie, G., \& Choy, S. (1998). The readiness of VET clients for flexible delivery including online learning. Brisbane: Australian National Training Authority.

Warren, M. (2007). The digital vicious cycle: Links between social disadvantage and digital exclusion in rural areas. Telecommunications Policy. https://doi.org/10.1016/j.telpol.2007.04.00 1

Yukselturk, E., \& Bulut, S. (2007). Predictors for student success in an online course. Educational Technology and Society.

Zaharah, Z., \& Kirilova, G. I. (2020). Impact of Corona Virus Outbreak Towards Teaching and Learning Activities in Indonesia. SALAM: Jurnal Sosial Dan Budaya Syar-I. https://doi.org/10.15408/sjsbs.v7i3.15104 